University of Nebraska - Lincoln

DigitalCommons@University of Nebraska - Lincoln

1998

\title{
Influence of Soybean Canopy Closure on Predator Abundances and Predation on Helicoverpa zea (Lepidoptera: Noctuidae) Eggs
}

\author{
Aaron C. Anderson \\ University of Kentucky, Lexington \\ Kenneth V. Yeargan \\ University of Kentucky, Lexington
}

Follow this and additional works at: https://digitalcommons.unl.edu/entomologyother

Part of the Entomology Commons

Anderson, Aaron C. and Yeargan, Kenneth V., "Influence of Soybean Canopy Closure on Predator Abundances and Predation on Helicoverpa zea (Lepidoptera: Noctuidae) Eggs" (1998). Entomology Papers from Other Sources. 113.

https://digitalcommons.unl.edu/entomologyother/113

This Article is brought to you for free and open access by the Entomology Collections, Miscellaneous at DigitalCommons@University of Nebraska - Lincoln. It has been accepted for inclusion in Entomology Papers from Other Sources by an authorized administrator of DigitalCommons@University of Nebraska - Lincoln. 


\title{
STEMBORERS ASSOCIATED WITH SMOOTH CORDGRASS, SPARTINA ALTERNIFLORA (POACEAE), IN A NURSERY HABITAT
}

\author{
W. H. WHITE ${ }^{1}$, D. ADAMSKI ${ }^{2}$, G. FINE $^{3}$ AND E. P. RICHARD, JR. ${ }^{1}$ \\ ${ }^{1}$ USDA, ARS, Southern Regional Research Center, Sugarcane Research Unit, Houma, LA 70360
}

${ }^{2}$ USDA, ARS Systematic Entomology Laboratory, c/o National Museum of Natural History, Washington, DC

${ }^{3}$ USDA, NRCS Golden Meadow Plant Materials Center, Galliano, LA 70364

\begin{abstract}
Extensive ecological studies have been conducted on insects inhabiting native stands of smooth cordgrass, Spartina alterniflora Loisel; however, this is not the case for insects found in smooth cordgrass in a nursery habitat. We investigated species composition and larval disposition among stemborers (Lepidoptera: Coleophoridae and Crambidae) infesting stems of smooth cordgrass in nursery plots. One thousand and forty stems of smooth cordgrass were randomly selected in 2003 and examined for presence of stemborer larvae. Height of larvae on or within stem, height of stem from ground level to top-visible dewlap, and condition of the leaf-whorl were documented. Stemborers representing six species of Lepidoptera were recovered. These species were Blastobasis graminea Adamski (Lepidoptera: Coleophoridae); a four-species complex comprised of Diatraea saccharalis (F.), Chilo demotellus Walker, Chilo plejadellus Zincken, and Thaumatopsis probably actuella Barnes \& McDunnough (Lepidoptera: Crambidae); and Donacaula probably unipunctella Robinson (Lepidoptera: Crambidae). Larvae were generally on different parts of the stem and, with the possible exception of larvae of the four-species complex, seemed unlikely to contact one another. Blastobasis graminea was the most abundant species collected $(n=128 ; 52 \%)$ and was located at the base of the stem (eq $\bar{x}$ eqx- $=6.7 \pm 5.4 \mathrm{~cm}$ ). The four-species complex was the next most abundant $(n=85 ; 35 \%)$ and was always found within the stalk about mid-way up the stem (eq $\bar{x}=16.7$ $\pm 8.6 \mathrm{~cm})$. Donacaula sp. was the least abundant species $(n=32 ; 13 \%)$ and was always found in the tight leaf-whorl just above the stem meristem (eq $\bar{x}=23.6 \pm 15.4 \mathrm{~cm}$ ). A total of 544 (52\%) of the stems sampled had a dead leaf-whorl, but only $140(26 \%)$ were infested. Stemborer species did not significantly affect the number of plants with and without deadhearts.
\end{abstract}

Key Words: Lepidoptera, Crambidae, Coleophoridae, pest introductions, sugarcane

\section{RESUMEN}

Estudios ecológicos extensivos han sido realizados sobre los insectos que habitan los campos nativos de Spartina alterniflora Loisel; sin embargo, este no es el caso para los insectos encontrados en S. alterniflora el los viveros. Nosotros investigamos la composición de especies como la disposición de larvas de los barrenadores (Lepidoptera: Coleophoridae y Crambidae) que infestan las parceles de S. alterniflora en los viveros. Mil y cuarenta tallos de S. alterniflora fueron seleccionados al azar en 2003 y examinados para la presencia de larvas de barrenadores. La altura de la posición de las larvas encima o adentro el tallo, la altura desde el nivel de tierra hasta al nivel la parte apical de la planta donde la hoja empieza doblarse, y la condición de espiral de la hoja fueron documentados. Barrenadores representando seis especies de Lepidoptera fueron recolectados. Estas especies son: Blastobasis graminea Adamski (Lepidoptera: Coleophoridae); un complejo de cuatro especies compuesto de [Diatraea saccharalis (F.), Chilo demotellus Walker, Chilo plejadellus Zincken, y Thaumatopsis probablemente actuella Barnes \& McDunnough (Lepidoptera: Crambidae)]; y Donacaula probablemente unipunctella Robinson (Lepidoptera: Crambidae). Las larvas generalmente fueron encontradas sobre distintos partes de los tallos y con la posible excepción de larvas del complejo de cuatro especies, parece poco posible el tener contacto entre ellas. Blastobasis graminea fue la especie mas abundantemente recolectada $(n=128 ; 52 \%)$ y fue encontrada en la base del tallo $(\bar{x}=6.7$ $\pm 5.4 \mathrm{~cm})$. El complejo de cuatro especies fue la siguiente categoria mas abundante $(n=85$; $35 \%$ ) y siempre fue encontrada dentro del tallo aproximadamente en la mitad de la altura del tallo $(\bar{x}=16.7 \pm 8.6 \mathrm{~cm})$. Donacaula $\mathrm{sp}$. fue la especie menos abundante $(n=32 ; 13 \%)$ y fue encontrada en la espiral apretada de hojas un poco mas arriba del meristema del tallo $(\bar{x}=$ $23.6 \pm 15.4 \mathrm{~cm})$. Un total de $544(52 \%)$ de los tallos muestreados tenian una espiral de hojas muertas, pero solamente $140(26 \%)$ de ellos fueron infestados. Las especies de barrenadores no afectaron significativamente el número de las plantas con y sin corazones muertos. 
Smooth Cordgrass, Spartina alterniflora Loisel, dominates the vegetation of many Atlantic, Gulf, and Pacific intertidal marshes, often occurring in pure stands. In Louisiana, smooth cordgrass vegetation increases in early spring to a peak in September that corresponds with flowering. After flowering there is rapid death of the aboveground portions of the plants to a minimum standing crop in December, although new sprouts are present even in December and January (Kirby \& Gosselink 1976). For an in depth discussion and review of the habitats and growth form of cordgrass in the U.S., see Denno et al. (1996).

Smooth cordgrass is a sustainable and renewable restoration resource that provides shoreline protection and a foundation for near-shore building (Materne 2000). Artificial plantings of smooth cordgrass for restoration and stabilization projects have become widespread throughout coastal Louisiana and, as a result, a nursery industry is developing to meet the increased need for smooth cordgrass plant material. To assist this developing industry, research is underway to establish optimum procedures for propagating plants in nursery habitats. Research thus far has focused on agronomic and pathological aspects of seedling propagation (Harrison et al. 2001). We are unaware of research conducted on the impact of insect feeding on smooth cordgrass in nursery situations. However, planthoppers in the genus Prokelisia are the focus of extensive ecological studies in smooth cordgrass in natural habitats. In mid Atlantic coast salt marshes, Prokelisia comprise $95-99 \%$ of all herbivores samples on smooth cordgrass (Denno et al. 1987).

In 2002, while conducting a survey in Texas and Louisiana for the sugarcane pest, Blastobasis graminea Adamski (Lepidoptera: Coleophoridae) (White et al. 2005), we discovered $B$. graminea in smooth cordgrass nursery plots at the USDA, NRCS Golden Meadow Plant Materials Center, Galliano, LA. Coincidentally, we found a second stemborer associated with cordgrass plants in the same plots. In a followup survey in 2003 , we found what appeared to be a third species of stemborer also infesting stems of cordgrass in these plots. After numerous plant dissections, it became apparent that these stemborers were utilizing different areas of the plant. We therefore conducted a survey of the nursery to validate these observations and to survey for additional stemborers that may have heretofore gone undetected or unreported from smooth cordgrass. In particular, we searched for those stemborers found in smooth cordgrass that may be important pests of sugarcane, such as other species of Diatraea or the Mexican rice borer, Eoreuma loftini (Dyar) (Lepidoptera: Crambidae). Presented here are the results of that survey.

\section{MATERIALS AND METHODS}

Sixteen smooth-cordgrass plots were planted at the USDA, NRCS Golden Meadow Plant Materials Center, Galliano, LA on 18 April 2001. The plots were established from vegetative propagules obtained from 120 smooth cordgrass selections collected throughout coastal Louisiana in 1999. Propagules were blended and planted with a one-row mechanical transplanter set on 102-cm rows. Eight plots were established; each plot was $6 \mathrm{~m}$ wide by $33 \mathrm{~m}$ long and with a $4-\mathrm{m}$ wide buffer between plots.

On 11 June 2003, 65 stems were randomly removed from the middle three rows of a five-row plot and bundled together (1040 stems total). All stems were cut at the base of the stem at ground level. Bundles were brought back to the laboratory and immediately placed in cold storage $\left(9^{\circ} \mathrm{C}\right)$ to reduce the possibility of larvae redistributing themselves on stems before examination. Bundles were removed from cold storage one-by-one and the stems were carefully examined externally for the presence of larvae and then dissected. All larvae found were removed from the plant and their associated height from the base of the plant was recorded. We also measured plant height from ground level to top-visible dewlap and noted if the leaf-whorl emanating from the stem meristem was dead or not.

Data were analyzed by the PROC MIXED procedure (SAS 2001) as a randomized complete block design with eight replications; stalks within plots were considered as a subsample. Chi-square comparisons were determined by the PROC FREQ (SAS 2001).

All larvae collected were placed on a commercial sugarcane borer diet (Southland Products ${ }^{\circledR}$ Lake Village, AR) and stored in a growth chamber $\left[30^{\circ} \mathrm{C}, 0: 24\right.$ (L:D)]. Identifications were based upon moths sent to the USDA, ARS, Systematic Entomology Laboratory, Washington D.C. for species determinations. Vouchers of adult moths are deposited at the USDA, ARS, Sugarcane Research Unit, Houma, LA.

\section{RESULTS}

Of the stems sampled, 218 (20\%) supported at least one larva, whereas an additional $179(17 \%)$ exhibited evidence of prior insect feeding but no larvae were recovered. A total of 245 stemborer larvae were recovered, representing four species and two genera (species undetermined) of Lepidoptera (Table 1). The sugarcane pest, $B$. graminea, was the most abundant species recovered (Table 2 ). Collected larvae readily accepted the rearing medium, and a large number of adults developed from larvae placed on diet. Another 85 larvae were recovered from within the stem and, as a group, were the next most abundant and were considered 
TABLE 1. STEMBORERS COLLECTED FROM SMOOTH CORDGRASS DURING SURVEYS IN 2003.

\begin{tabular}{ll}
\hline Species & Previously reported from Cordgrass \\
\hline $\begin{array}{l}\text { Coleophoridae: Blastobasinae } \\
\text { Blastobasis graminea }\end{array}$ & Yes (White et al. 2005) \\
Stemborer complex & \\
Crambidae: Crambinae & \\
Diatraea saccharalis & \\
Chilo demotellus* & No \\
C. plejadellus* & Yes (Stiling \& Strong 1983) \\
Thaumatopsis sp.* & Yes (Neunzig, H. H. 1987) \\
Crambidae: Schoenobiinae & No \\
Donacaula sp. & \\
\hline
\end{tabular}

*Collected from cordgrass in 2003 , but not as part of this study.

a complex in this study, as we were unable to obtain identifications from larval specimens. A single specimen of the sugarcane borer was the only larva from the complex to complete development and, consequently, the only species identified from this particular survey. None of the other 85 specimens collected completed development, even when the diet was supplemented with $20 \mathrm{~g}$ (10\% of total dry mix) of freeze-dried cordgrass tissue. However, we were able to retrieve from additional smooth cordgrass collections made in 2003, similar larvae from the same position on the cordgrass plant that did develop into adults. These specimens were identified as: Chilo demotellus Walker, Chilo plejadellus Zincken, and Thaumatopsis probably actuella Barnes \& McDunnough. Finally, Donacaula probably unipunctella Robinson was the least-abundant species and difficult to rear. Larvae of this species fed on the diet but did not pupate. Adding freeze-dried host tissue appeared to elicit greater feeding by larvae of this species, but did not increase pupation. Ultimately, smoothgrass plants were transplanted to pots in the greenhouse and infested with additional field-collected larvae before a single adult specimen was fi- nally obtained, and was the basis for species determination for this report.

Stemborer larvae were stratified on the cordgrass plant (Fig. 1). B. graminea was generally found on the lower portions of the plant and more narrowly distributed in that area. The stemborer complex was located approximately midway up the cordgrass stem. However, as the cordgrass stem is hollow and therefore permits free movement of the larva within the stem, these larvae were more widely distributed in individual stems than B. graminea. Donacaula sp. also appeared widely distributed along the stem, but was always found in the tight leaf-whorl above the apical meristem. For the figure, we considered all stems as single infestation even though two of the stems we collected contained multiple individuals of the four-species complex. Therefore, the number collected for this group reported in the figure differs from the number reported from the table.

A total of $544(52 \%)$ of the stems sampled had a dead stem meristem, as evidenced by a dead leaf-roll, a condition referred to as a deadheart or a whitehead. Presence of a deadheart was a poor indicator of the presence of a stemborer. Of the

TABLE 2. SUMMARY OF STEMBORER SPECIES RECOVERED, ABUNDANCE, AND LOCATION ON SMOOTH CORDGRASS IN 2003.

\begin{tabular}{|c|c|c|c|}
\hline Species & Mean number per plot ${ }^{1}$ & Mean height on plant $(\mathrm{cm})^{1}$ & $\begin{array}{l}\text { Mean height on plant } \\
\text { as } \% \text { of plant height }\end{array}$ \\
\hline B. graminea & $8(128)^{2} \mathrm{~A}$ & $6.7 \mathrm{~A}$ & $16.0 \mathrm{~A}$ \\
\hline Stemborer Complex & $5(85) \mathrm{B}$ & $16.7 \mathrm{~B}$ & $42.4 \mathrm{~B}$ \\
\hline Donacaula sp. & $2(32) \mathrm{C}$ & $23.6 \mathrm{C}$ & $66.3 \mathrm{C}$ \\
\hline $\operatorname{LSD}(P=0.05)$ & 2.8 & 4.9 & 8.5 \\
\hline
\end{tabular}

${ }^{1}$ Means in a column followed by the same letter are not significantly different (0.05) based on the LSD test, PROC MIXED (SAS 2001); $d f=2 ; \operatorname{Pr}>F=0.0004,<0.001,<0.001$ for mean number per plot, mean height on plant, and mean height on plant as $\%$ of plant height, respectively.

${ }^{2}$ Numbers in parentheses are the total number of larvae collected. 


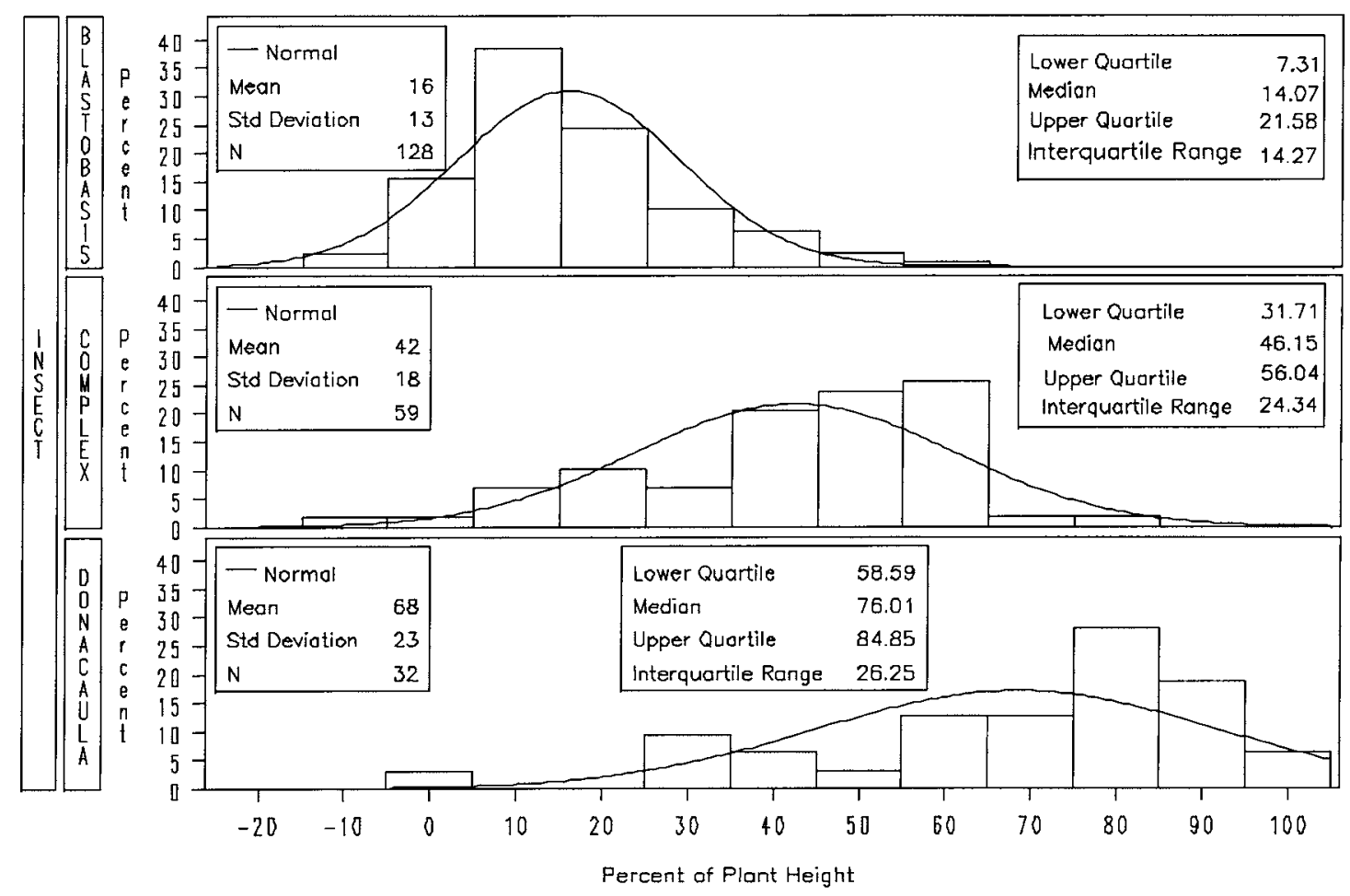

Fig. 1. Distribution of stemborers on smooth cordgrass plants with location on plant expressed as a percentage of plant height measured at the top visible dewlap.

544 stems collected with a deadheart, only 140 (26\%) were actually infested. Stemborer species did not significantly affect the number of plants with and without deadhearts as determined by chi-square test $(P>0.05)$.

\section{DISCUSSION}

We were unable to obtain adult specimens of several of the stemborers collected. Consequently we were unable to obtain definitive identifications for all specimens collected. This deficiency plus a relatively small sample size, prevents us from commenting to any great extent on the degree of interspecific or intraspecific competition that may have existed among the various moth taxa collected in our survey. With the exception of the four-species complex, the various species were generally found on different parts of the stem, albeit with some degree of overlap.

Rarely was more than a single individual stemborer found on the same plant. We observed $B$. graminea, the four-species complex, and an unidentified curculionid sharing the same plant, although not in large numbers. This was not the case with Donacaula sp., as only once was it found on a plant occupied by another stemborer and never with another Donacaula. At least one spe- cies of the complex apparently deposited eggs in masses as we observed two plants each containing multiple larvae. One plant contained 20 individuals and the other six. We could not determine if the larvae of this species were cannibalistic or if the larvae disperse to other plants as their development progresses.

Rathcke (1976) suggests that hollow stems may increase chances of larval encounters. Smooth cordgrass stems, with the exception of very small stems, are hollow. Thus, interspecific and intraspecific competition may have occurred among the four-species complex. Stiling \& Strong (1983) report interspecific competition between C. demotellus and Languria taedata LeConte (Coleoptera: Languriidae), two species that share a similar niche on the smooth cordgrass plant. We also found specimens of an unidentified languriid in our survey, but only a few individuals were found and these were not found in the presence of another stemborer.

It is not certain how important the stemborer species reported in this study are in reducing plant stands or causing failure of the plant to flower, as we took no measures of damage other than deadhearts. In native stands, none of the larvae encountered in our surveys were ever found in as high numbers as what we found in our 
nursery situation. It will be important to validate the species identity of those stemborers reported in our survey and to learn more of their biology in order to develop effective control tactics, should they be needed. With the discovery of $B$. graminea for the first time in U.S. in smooth cordgrass in 2002 , it will also be important to closely monitor the movement of nursery material (both interand intra-state), as it may serve as the host of introduction of important insect pests of sugarcane and other gramineous crops.

\section{ACKNOWLEDGMENTS}

We thank Garris Thomisee, Dawn Bagala, and Cherokee Trosclair of the USDA, NRCS Plant Materials Center, Golden Meadow, LA, and Randy Richard, Chris Finger, and Brain Duet of the USDA, ARS, Sugarcane Research Unit, Houma, LA, for technical assistance. Dr. M. Alma Solis, USDA, ARS, Systematic Entomology Laboratory, provided identification of Crambidae. We also thank Ms. Debbie Boykin, Area Statistician, USDA, ARS, Mid-South Area, Stoneville, MS, for assistance in statistical analysis. Mention of trade names or commercial products in this article is solely for the purpose of providing specific information and does not imply recommendation or endorsement by the U.S. Department of Agriculture.

\section{REFERENCES CITED}

Denno, R. F., M. E. Schauff, S. W. Wilson, AND KAREN OLMSTEAD. 1987. Practical diagnosis and natural history of two sibling salt marsh-inhabiting plan- thoppers in the genus Prokelisia (Homoptera: Delphacidae). Proc. Entomol. Soc. Wash. 89: 687-700.

Denno, R. F., G. K Roderick, M. A Peterson, A. F. Hubery, H. G. DöBEL, M. D. Eubanks, J. E. Losey, AND G. A. LANGELLOTTO. 1996. Habitat persistence underlies intraspecific variation in the dispersal strategies of planthoppers. Ecological Monographs 66: 389-408.

Harrison, S. A., T. P. C., M. D. Materne, B. C. Venuto, G. A Breitenbeck, M. A. Cohn, X. FAng, A. RYAN, R. W. SchneIder, R. A. Shadow, P. SubUDHI, AND H. UTOMO. 1987. 2001. Improving native plants to protect and preserve Louisiana's coastal marshes. Louisiana Agriculture. 44: 4-6.

KIRBY, C. J., AND J. G. GosselinK. 1976. Primary production in a Louisiana Gulf Coast Spartina alterniflora marsh. Ecology 57: 1052-1059.

MATERne, M. 2000. Plant Guide Spartina alternaflora Smooth Cordgrass. LSU AgCenter Communications. Baton Rouge, LA.

NeunZIG, H. H. 1987. Pyralidae (Pyraloidea), pp. 462 494 In F. W. Stehr [ed.], Immature Insects. V. 1. Kendall/Hunt Publishing Company, Dubuque, IA. 754 pp.

RATHCKE, B. J. 1976. Competition and coexistence within a guild of herbivorous insects. Ecology. 57: 76-88.

SAS. 2001. SAS System Release 8.2. SAS Institute, Inc., Cary, NC, USA.

STILING, P. D., AND D. R. STRONG. 1983. Weak competition among Spartina stem borers, by means of murder. Ecology. 64: 770-778.

White, W. H., D. AdAMski, J. Brown, T. E. REAGAN, J. A. Villanueva-Jimenez, M. MENDEZ-LOPEZ, AND M. O. WAY. 2005. Survey results for the sugarcane pest, Blastobasis graminea (Lepidoptera: Coleophoridae), in Texas and Louisiana in 2002. Southwestern Entomol. (In Press). 